Article

\title{
Forest Values and Forest Management Attitudes among Private Forest Owners in Sweden
}

\author{
Annika Nordlund ${ }^{1, *}$ and Kerstin Westin ${ }^{2}$ \\ 1 Department of Psychology, Umea University, SE-901 87, Umea, Sweden \\ 2 Department of Social and Economic Geography, Umea University, SE-901 87, Umea, Sweden; \\ E-Mail: kerstin.westin@geography.umu.se \\ * Author to whom correspondence should be addressed; E-Mail: annika.nordlund@ psy.umu.se; \\ Tel.: +46-90-786-7830; Fax: +46-90-786-6695.
}

Received: 01 November 2010 / Accepted: 20 December 2010 / Published: 29 December 2010

\begin{abstract}
The present study focused on how forests will be managed in the future in light of the increased emphasis being put by the public on the ecological and recreational values of forests, the trend towards an increased share of non-resident forest owners, and the increased female forest ownership. The value and belief basis of forest management attitudes was explored using a questionnaire sent to a sample of private forest owners 'residing on' $(\mathrm{n}=995$, return rate $=51.3 \%)$ and 'not residing on' the forest property $(n=997$, return rate $=50 \%)$. The results showed that a share of private forest owners strongly value both the view that the forest should predominately be used for timber production and the view that preservation is most important. The proposed hierarchical structure of influence, in which the forest management attitude was influenced by values and beliefs, was supported in the study. The ecological, recreational, and production forest values primarily influenced the most closely related forest management attitude, even if some cross-sectional effects and some effects of socio-demographics were found, showing that the view a private forest owner has on different forms of management styles is shaped by the perceived multiple values of the forest.
\end{abstract}

Keywords: private forest owners; forest values; forest management attitudes; socio-demographics 


\section{Introduction}

Ever since early industrialization, forests have played an important role in economic development in countries in the northern hemisphere, for example, Sweden, Finland, Russia and Canada. Initially, the value of forests for primarily timber and tar production was recognized, and later pulpwood and pulp became significant products. When the scope is broadened to also include people's views on the forest resources, it becomes clear that people's attitudes and perceptions of forests and forest utilization have changed; ecological and recreational values have become increasingly important, while economic (traditional production) values are perceived as less important [1,2]. This change may be partly related to a population redistribution process in which urban regions have continued to grow and rural forest areas to decline, leading to an increased distance between people and forests. Further, the importance of the primary sector for employment has declined [3], resulting in less personal economic dependency on the forest sector.

During the past decade, the environmental and recreational perspectives have become integrated parts of the debate, for example, forests are also important as carbon sinks for biodiversity and for protecting rare or endangered species, as well as for leisure time, recreation and experiencing 'nature'. Hence, today forests are characterized by multiple uses, and it is quite accepted for private forest owners to associate multiple values with their forests resource-restoration, conservation, production, maintenance, etc. [4-13]. In addition to multiple uses of forests, there are also multiple rationales for forest management. The multiple uses - and demands - have resulted in forests becoming, to an increasing extent, an arena for conflicting interests and diverging opinions on how forests should, and should not, be managed [14].

A little more than half of Sweden's land area consists of forest land-22.5 million hectares productive forest land out of a total of 40.8 million hectares - and about half of the forest land is privately owned [15]. Largely as a consequence of population redistribution and economic restructuring, the character of the private forest owners is changing. The number of non-resident forest owners, i.e., those not living in the municipality where their forest property is located, is increasing. Non-resident forest owners often reside in cities, and forest protection values have been shown to be significantly higher among urban residents [16]. The fact that there is a large group of non-resident forest owners who are not primarily dependant on forest revenues and not part of the local community in which the forest is located, raises the question of whether non-resident owners differ from resident owners in how they value and manage the forest. Further, the number of female owners is increasing, and now amount to almost 40 percent of all private forest owners [16]. Women tend to have a more ecological environmental orientation than men do [17], which may also affect their forest values. Young people emphasize preservation to a higher degree than older people [16]. The private forest owners in Sweden are older, but in the years to come a generational change will naturally take place. Not only will the owners be younger, but they will also have different education levels, occupations, etc., which may influence the objectives of forest ownership [18]. These new characteristics of forest owners raise the question of whether there are conflicting interests between and within different groups (resident vs. non-resident owners, men vs. women, young vs. old, etc.) with respect to economic, ecological and recreational values and forest management. 
In light of the increased emphasis being put by the public on the ecological and recreational values of forests and the new characteristics of forest owners, the question arises of how forests will be managed in the future. In the present article, we focus on private forest owners, our objective being to investigate their forest values and forest management attitudes.

The following questions are scrutinized:

1. What characterizes residential and non-residential forest owners?

2. Do forest owners have conflicting forest values (e.g., recognizing production as well as ecological values)?

3. To what extent can general and specific values and beliefs predict attitudes towards different forms of forest management (environmental, human-centered and economic management)?

Researchers have stressed the importance of assessing the full range of variables that motivate a certain behavior [19-21], and in the present study the relations between general values, environmental values, forest values, forest beliefs, and forest management attitudes are in focus, as well as how much explained variance remains from values and beliefs when different socio-demographics are controlled. An overarching aim of the study is to build a theoretical framework on the long-standing body of research within the field of environmental psychology, using well-established measurements and models in order to integrate attitude research from an environmentally relevant behavioral perspective with the forest management perspective.

\section{Theoretical Framework}

\subsection{Values in Inner Conflict or Congruence?}

Because the forest can be used in such a variety of ways, conflicts concerning the way it should be used are to be expected [14]. Some may feel that the forest should predominately be used for timber production, while others may believe that preservation is most important. Such diverging views create conflicts between different groups in society. It is further possible that conflicts may arise within the individual, that is, a conflict between the forest values and attitudes held by him or her.

One overarching dilemma, potentially leading to conflicting values, may be the current high level of environmental awareness, which may lead to demands for conservation of the forest resource or eco-friendly forest management. It may also lead, however, to a high demand on the forest resource for recreation and eco-tourism and a high demand for wood products at times when, due to resource depletion, a shift from oil-based products to wood products may be necessary. The presence of potential conflicts between different forest values has been shown in a sample of the Swedish general public [22]. Members of the general public did exhibit a potential conflict, or cognitive dissonance, between strong production forest values and strong ecological forests values. The question posed here is whether such potential conflicts between different types of forests values also exist in a sample of private forests owners. 


\subsection{Values, Beliefs, and Attitudes-A Hierarchical Structure with an Influence on Forestry}

In the present study, attitudinal factors are defined according to the inter-attitudinal structure of attitudes [23], meaning that values, beliefs, and attitudes are part of a hierarchical cognitive structure (see e.g., [24-27]). Values are defined as core elements that transcend specific situations and, as such, as basic building blocks of this hierarchical structure, in which values are linked to attitudes and beliefs as well as to other values. Beliefs have been described as thoughts and opinions we have concerning an attitude object [24], and attitudes are commonly defined as a positive or negative evaluation of an attitude object [23]. Attitudes are thus seen as being linked to other attitudes in a hierarchical manner, in which more particular attitudes or beliefs are developed that are consistent with the individual's values, enabling the individual to express and act on those values. The most investigated aspect of the inter-attitudinal structure of environmental attitudes is the relation between these attitudes and values [24]. One example of this is the work of Stern, Dietz, Kalof and Guagnano [28], which focused on the hierarchical inter-attitudinal structure of environmental attitudes. People tend to fall back on their values to develop a position when faced with a specific environmental dilemma. What this means in terms of the concepts of attitude research is that when environmental attitudes are deduced from values, they are in fact generalized from more abstract attitudes. Values, beliefs, attitudes, intentions, and behavior have been shown to be related to natural resource management in general [29-34], and to forest-related behavior in particular [35-37]. Basic values do seem to influence general beliefs, specific attitudes, and subsequently forest-related behaviors (e.g., boycotting products) in a hierarchical manner.

Values, or so-called primitive beliefs, have traditionally been regarded as core aspects of the self-concept [38]. One approach often used when studying the effects of values on proenvironmental behavior is found in Value Theory. According to Schwartz [31], values transcend situations, vary in importance, and function as guiding principles in life, and for beliefs and attitudes pertaining to specific issues (e.g., forest management). One common measure of values is Schwartz's [31,39] Value Inventory Scale, which assesses ten distinct value types representing underlying motivational structures. These value types can be described using two dimensions: openness to change vs. conservation and self-transcendence vs. self-enhancement. Openness to change vs. conservation reflects the distinction between individuals' willingness to act independently and their unwillingness to change, while self-transcendence vs. self-enhancement reflects the distinction between values oriented towards the pursuit of self-interest and values oriented towards the welfare of others. Self-transcendence thus serves collective interests, combining value types such as universalism and benevolence, while self-enhancement serves individual interests, combining value types such as power and achievement. Several studies have shown that people who prioritize self-transcendent values show a higher willingness to engage in different forms of altruistic, cooperative, or proenvironmental behavior than do people who prioritize self-enhancement values [28,32,38-40]. Most studies dealing with environmental issues have only focused on the dimension self-transcendence $v s$. self-enhancement. In the present study, however, we find it interesting to analyze the potential influence of both value dimensions and thus to discover whether both can explain the unique variance in different forests management attitudes. 
Another important basic aspect is the primitive beliefs people have about the nature of the earth and the human relationship with it. The New Environmental Paradigm (NEP) [41] is a widely used scale that assesses beliefs about humans' ability to upset the balance of nature, the existence of limits to the growth of human society, and the human right to rule over the rest of the world, in essence a form of environmental problem awareness. The scale assesses three facets-balance of nature, limits to growth, and humankind's domination of nature - and has been shown to be successful in predicting behavioral intentions and behavior. A revised version of the scale, the New Ecological Paradigm Scale, has been developed, and this revised measure of an individual's ecological worldview has likewise been shown to be related to proenvironmental behavior [42]. Environmentally related values have been categorized in similar ways by several researchers [17,32-33,43-46], and there is current support for a three-way distinction of values - egoistic, altruistic, and biospheric value orientation - and for the notion that these are useful for examining environmentally relevant behaviors of different kinds [47]. Related to this reasoning are the values and beliefs specifically focused on the forest. Forest values, defined in line with the above-mentioned three-way distinction, have been studied within forest research [18]. However in Sweden's long history of forestry, forest research on values has primarily focused on how attitudes have been formed and expressed in economic terms [48]. On the other hand, there has been a shift in forestry towards management of multiple values and recognition of the important role of non-timber values in sustainable forest management, including ecological, aesthetic, and recreation values [49-51]. This shift has been motivated by an increase in public awareness of environmental and forestry issues [52]. Forest values are thus beliefs that represent an individual's orientation toward forests [35], and these values are have been shown to be related to our social structures and identity, through our level of experience with the forest and the people we network with [53]. Forests values cannot be depicted as one-dimensional, instead the concept should be seen as multi-dimensional [54]. In the present study, forest values are defined as values expressing the ecological value, the recreational value, and the production value related to the forest, much like the above-described three-way distinction of values as egoistic, altruistic, and biospheric. People also have beliefs about attitude objects, and these beliefs are viewed as the basic building blocks of attitudes. In relation to forestry, various beliefs, such as those concerning growth in forestry and the importance of forest revenues, may be important to forest management attitudes. The belief in the importance of forest revenues relates to the more traditional form of forestry, before the multiple values of the forest were accentuated. The belief in increased forest production as a way to meet the increased demand for wood products, on the other hand, relates to current discussions about a more intensified forestry. Such specific forest beliefs may be important to forest management attitudes.

People have attitudes about most things, the forest as an entity and forest management being no exception. Attitudes, defined as an internal psychological tendency, are people's way to express an evaluation of a given entity with some degree of favor or disfavor [23]. Attitudes have at least four different functions: A knowledge function, which resembles the schema concept, where schemata are required to make sense out of experiences; an adjustment or utilitarian function, which enables a person to maximize rewards and minimize punishments; an ego-defensive function, allowing people to protect themselves from unpleasant realities; and lastly a value-expressive function, enabling people to express their personal values and self-concept. Attitudes thus enable individuals to adapt to their environment, and the relation between attitudes and behavior is argued to be best understood by 
placing attitudes in the context of other psychological factors, such as values, beliefs, and norms, which determine behavior [23]. The relations between values, forest values and forest management attitudes have been examined in previous studies $[35,36,55,56]$, including the importance of sustainability in forest management (see $[29,35,36,52]$ ). Here, however, we aim to place forest values and attitudes towards different forms of forest management (Environmental Management Attitude; Human Centered Management Attitude; Economic Management Attitude) in the context of both more general values and beliefs and more specific beliefs related to forestry, in order to capture the complexity of attitude influence.

\subsection{The Present Study}

In the present study, the question of how forests will be managed in the future has arisen as a result of the increased emphasis being put by the public on the ecological and recreational values of forests, the trend towards an increased share of non-resident forest owners, and the increased female forest ownership. In addition, the value and belief basis of forest management attitudes is explored with a special interest in how general values, environmental values, forest values, and specific forest beliefs influence attitudes. The chosen focus on attitudinal factors can be seen in that forest values and forest management attitudes are placed in a context or model influenced by work on the value-belief-norm theory of environmentalism [57] and adaptations of this model pertaining to the forest sector [35] (see Figure 1). The chosen focus on attitudinal factors does not disregard the fact that there are other important causal factors, not covered within the scope of the present study, such as contextual factors in a wider sense, personal capabilities, and habits [20].

The effect of different socio-demographics on the values-beliefs-attitude relationship was controlled in the study. In addition, because forest values may be in conflict, it is also interesting to investigate whether such internal conflicts exist. One aim of the study was to investigate, in an explorative manner, whether the participating private forest owners experience internal conflicts in terms of their ecological forest values, recreational forest values, and production forest values. A second aim was to study whether the hierarchical structure concerning how general and specific values and beliefs influence forest management attitudes holds among private forest owners. More specifically, does the influence from values and beliefs primarily affect forest management attitudes in a hierarchical, or step-wise, manner? Lastly, an additional aim was to investigate the effects socio-demographic characteristics of forest owners have on forest management attitudes.

Figure 1. Conceptual representation of the proposed hierarchical model of the influence of values and beliefs on forest management attitudes.

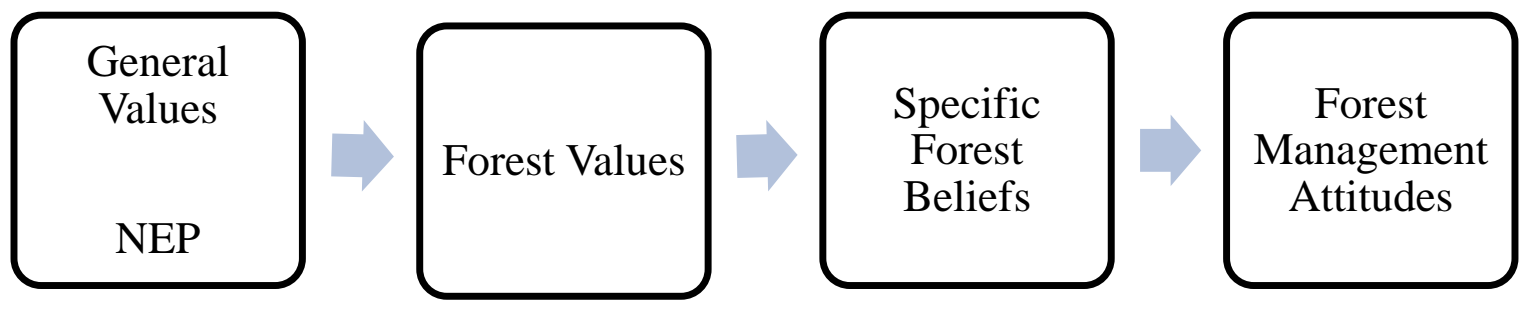




\section{Method}

The study was conducted through a postal questionnaire sent to a randomly selected sample of private forest owners: 995 resident owners (living in the municipality where their forest property was located) and 997 non-resident owners (not living in the municipality where their property was located). The survey was conducted during the period November 2009 to February 2010. The respondents were between 20 and 80 years of age, all residing in Sweden. After two reminders, the response rate for resident owners was 51.3 percent $(n=995)$ and for the non-resident owners 50.0 percent $(n=997)$. Statistics Sweden carried out the sampling, data collection, and quality control of the data, while the authors were responsible for the study design, the questionnaire and analyses.

An attrition analysis showed that the respondents are representative of the population of forest owners to a high degree in terms of owners' age, education level, income, and size and ratable value of the forest property. One deviation, however, is that men and also married forest owners are overrepresented among the respondents.

The questionnaire contained questions about the participant, forest-related beliefs and experiences, environmental beliefs, and values. Only the questions relevant to the study are described below. An overview of the items used to generate measures, response scales, and internal reliability of the index variables is provided in Table 1.

Socio-demographics. The respondents were asked a number of questions regarding their socio-demographics. The socio-demographics relevant here were the respondents' gender, age (20-80 years of age), the type of region they lived in (big city region, larger regional centers, smaller regional centers, small region), and how the respondents acquired their forest property (through purchase or inheritance).

General values. The respondents' general values along the two dimensions self-transcendence (ST) versus self-enhancement ( $\mathrm{SE}$ ) and openness to change (OC) versus conservatism (C) were assessed using a short version of Schwartz's [39] Value Inventory Scale. In total, twenty values were used, and each value was presented with a short description in brackets; the respondents were asked to indicate how important each value was as a guiding principle in their life on a nine-point scale. Of the total values, five were respectively combined into four higher order value types with high reliability (ST, SE, OC, and C). In order to control for scale use differences, the mean of the twenty values was used to adjust each higher order value score, and in order to obtain scores for each respondent on the two dimensions, ST vs. SE and OC vs. C, the higher order value indexes were factor analyzed using principal component analysis with a varimax rotation. The factor scores for each respondent were saved and used in correlation and regression analyses. The explained variance was 82 percent, and the solution indicated that the relation between the value indexes was approximately as expected, except that for the OC-C factor score, a positive effect in subsequent regression analyses would indicate an effect of conservative values and not vice versa.

Environmental values. The New Ecological Paradigm (NEP) scale [42] was used to assess environmental problem awareness. The respondents rated to what extent they agreed with the 15 items included on the scale. Seven of the items were reverse coded so that a higher value signified a stronger pro-environmental orientation. The means of the 15 items were combined into an index of environmental problem awareness with good reliability. 
Table 1. An overview of the measures in the study.

\begin{tabular}{|c|c|c|}
\hline Concept & Measures & Alpha \\
\hline Values & $\begin{array}{l}\text { We want you to indicate how important each and every one of the following values are as a guiding principle in your } \\
\text { life: }(1=\text { opposed to my values, } 2=\text { not important, } 5=\text { important, } 8=\text { very important, } 9=\text { extremely important }) \text {. }\end{array}$ & \\
\hline Self-transcendence & (1) Broad-minded, (2) Protecting the environment, (3) Social justice, (4) Helpful, (5) Loyal & $\alpha=0.73$ \\
\hline Self-enhancement & (1) Successful, (2) Social power, (3) Authority, (4) Influential, (5) Wealth & $\alpha=0.73$ \\
\hline Openness to change & (1) Freedom, (2) A varied life, (3) Independent, (4) Creativity, (5) Curious & $\alpha=0.75$ \\
\hline Conservation & (1) Self-discipline, (2) Family security, (3) Social order, (4) Respect for tradition, (5) Obedient & $\alpha=0.74$ \\
\hline $\begin{array}{l}\text { Environmental problem awareness } \\
\text { NEP }\end{array}$ & $\begin{array}{l}\text { To what extent do you agree with the following statements? }(1=\text { strongly disagree to } 5=\text { strongly agree }) \text {. } \\
15 \text { items. See [42] for the full list of items. }\end{array}$ & $\alpha=0.70$ \\
\hline Forest values & $\begin{array}{l}\text { The forest is a resource that can be used for different purposes. We want you to indicate how important you believe the } \\
\text { following is }(1=\text { not at all important to } 7=\text { very important }) \text {. }\end{array}$ & \\
\hline Ecological values & (1) Preservation of virgin forest/old-growth forest, (2) Preservation of plants and animals & $\alpha=0.74$ \\
\hline Recreation values & (1) Increase the number of areas for recreation in the forest, (2) Increased tourism in the forest landscape & $\alpha=0.84$ \\
\hline Production values & (1) Increased bio fuel production from the forest, (2) Increased timber production & $\alpha=0.59$ \\
\hline \multicolumn{3}{|l|}{ Specific forest beliefs } \\
\hline Forest revenues & $\begin{array}{l}\text { A forest property can give the owner different utilities/values. How important is forest revenues to you on your forest } \\
\text { property? ( } 1=\text { Not important at all to } 7=\text { Very important })\end{array}$ & - \\
\hline Forest production - demand & $\begin{array}{l}\text { To what degree are you positive or negative to increasing production in the forest as a way to meet an increased } \\
\text { demand? }(1=\text { Very negative to } 7=\text { Very positive })\end{array}$ & - \\
\hline Forest management attitudes & State the extent to which you agree with the following statements: $(1=$ strongly disagree to $7=$ strongly agree $)$. & \\
\hline $\begin{array}{l}\text { Environmental management } \\
\text { attitude }\end{array}$ & $\begin{array}{l}\text { (1) Areas with high nature values should be protected to a larger extent, } \\
\text { (2) The forestry should put more weight on protecting the biological diversity }\end{array}$ & $\alpha=0.78$ \\
\hline Human centered management & (1) The use of the forest should mainly consider the needs of the local tourism, & $\alpha=0.77$ \\
\hline attitude & (2) The use of the forest should mainly consider its meaning to public health, & \\
\hline & (3) The use of the forest should mainly consider its meaning to outdoor life & \\
\hline Economic management attitude & $\begin{array}{l}\text { (1) The use of the forest should mainly consider its meaning to the economy of forest owners, } \\
\text { (2) The use of the forest should mainly consider its meaning to the Swedish economy }\end{array}$ & $\alpha=0.61$ \\
\hline
\end{tabular}


Forest values. Three types of forest values were assessed in the present study, just as in Eriksson et al.'s [22] study on the general public: Ecological values, recreation values, and production values. The respondents were asked to rate how important different principles are in forest utilization. The means of the two items for each forest value type were combined into indexes, and the higher the value, the more important the particular forest value was to the respondent. The alpha value for the production value index was rather low, but considering that only two items were used to assess each type of forest value, the reliability was deemed reasonable.

Specific forest beliefs. Two specific beliefs were included in this particular study, that is, specific beliefs about the importance of revenues from one's own forest (forest revenue) and to what degree an increase in demand for forest products should be dealt with through an increased production rate in the forest (increased forest production). These two items assessing specific forests beliefs were used as single items and the level of reliability can therefore not be analyzed.

Forest management attitudes. Just as in Eriksson et al.'s [22] study on the general public, forest management attitudes were categorized as attitudes towards environmental forest management (e.g., emphasizing ecological principles), human-centered forest management (e.g., highlighting recreation interests in forest management), and economic forest management (e.g., with an economic focus). The respondents rated to what extent they agreed with a total of seven statements concerning principles that may guide forest management, where a higher value represented a more positive view of the given forest management strategy. The means of the items were combined into three indexes with reasonably high reliability.

\section{Results}

\subsection{Characteristics of Resident and Non-Resident Forest Owners}

Resident and non-resident owners show a number of different characteristics (see Table 2). Private forest owners are older than the Swedish population at large (Swedish Forest Agency, 2010), and the resident owners in the survey are on average somewhat older than the non-resident owners. The majority $(76 \%)$ of the owners are men; however, the share of female forest owners is significantly larger (28\%) among the non-resident owners than among the resident owners $(20 \%)$.

Further, it is more common for non-resident owners to have inherited their property, implying that resident owners have been more deliberate or active in their possession of land; they have purchased the property from the family $(44 \%)$ or on the open market $(20 \%)$. There is a significant gender difference in how the property was acquired; women have inherited or received the forest property to a higher extent than men have ( $32 \%$ and $54 \%$, respectively).

Of the resident owners, who by definition reside in the municipality their forest land is located in, 75 percent reside on their forest property. The other 25 percent live on average 40 kilometers from their property, in the countryside or in a small town (less than 2,000 inhabitants). The non-resident owners are more likely to live in urban areas; almost every third non-resident owner lives in a metropolitan area, and another 50 percent in large regional centers. The larger the place of residence, the longer the distance to the forest property; and non-resident owners living in metropolitan areas have on average 380 kilometers to their forest property. 
Table 2. Socio-demographic and value characteristics of resident and non-resident forest owners.

\begin{tabular}{|c|c|c|c|}
\hline & $\begin{array}{c}\text { Resident owners } \\
(\mathrm{n}=510)\end{array}$ & $\begin{array}{l}\text { Non-resident owners } \\
\qquad(\mathrm{n}=499)\end{array}$ & Total \\
\hline Women, \%** & $20 \%$ & $28 \%$ & $24 \%$ \\
\hline Average age, years & 61,9 & 62,1 & 62,0 \\
\hline Acquisition, $\% * * *$ (inheritance, gift) & $28 \%$ & $49 \%$ & $38 \%$ \\
\hline Sole owner, \%*** & $55 \%$ & $48 \%$ & $52 \%$ \\
\hline \multicolumn{4}{|l|}{ Residential region ${ }^{1} * * *$} \\
\hline metropolitan, \% & $14 \%$ & $30 \%$ & $22 \%$ \\
\hline larger regional center & $48 \%$ & $50 \%$ & $49 \%$ \\
\hline small regional center & $24 \%$ & $15 \%$ & $20 \%$ \\
\hline small region, $\%$ & $14 \%$ & $5 \%$ & $10 \%$ \\
\hline Total forest area, mean, hectare $* *$ & 97 ha & 116 ha & 101 ha \\
\hline Forest revenue $^{2} * *$ & 1,75 & 1,53 & 1,64 \\
\hline \multicolumn{4}{|l|}{$* * * \mathrm{p}<0.001, * * \mathrm{p}<0.01, * \mathrm{p}<0.05$} \\
\hline \multicolumn{4}{|c|}{${ }^{1}$ Based on the classification of Sweden into economic regions made by the Swedish Agency for Economic and Regiona } \\
\hline \multicolumn{4}{|c|}{ Growth. Metropolitan regions consist of the three largest city regions Stockholm, Gothenburg and Malmoe; } \\
\hline \multicolumn{4}{|c|}{${ }^{2}$ Forest revenue in relation to total yearly income measured on a scale where $1=$ almost nothing (an insignificant part), anc } \\
\hline
\end{tabular}

Most respondents have one forest property; however, every fourth forest owner has two or more properties. The separate forest properties vary between five and 970 hectares, and the non-resident owners have larger properties per se, but also a larger total forest possession than do the resident owners. Not only do the non-resident owners have larger forest estates, they also have a significantly larger income than the resident owners do, which reflects the fact that members of the former group are more likely to be gainfully employed and to not have to totally rely on forest incomes, while a larger proportion of resident owners are self-employed, with businesses based on their forest. When assessing the monetary importance of their forest possession, revenues from the forest were also rated to be of lower importance to the non-resident owners than to the resident owners.

\subsection{Forest Values}

The forest properties represent different utilities or values to the owners. In general, the resident owners value the direct and tangible aspects of owning their forest; it is a place to live, it provides them with bio fuel in the form of burning wood, and they value the opportunities of outdoor life (see Figure 2). The non-resident owners value most the opportunities of outdoor life, while the other aspects of ownership are more similar in valuation. Men and women agree to a large extent on the utilities of owning the forest property; however, men find the possibilities of hunting and fishing more important than women do, while women put more emphasis on picking berries and mushrooms, and on maintaining contact with family and friends. 
Figure 2. Importance of different aspects/utilities of forest ownership. $* * * p<0.001$, $* * \mathrm{p}<0.01, * \mathrm{p}<0.05$.

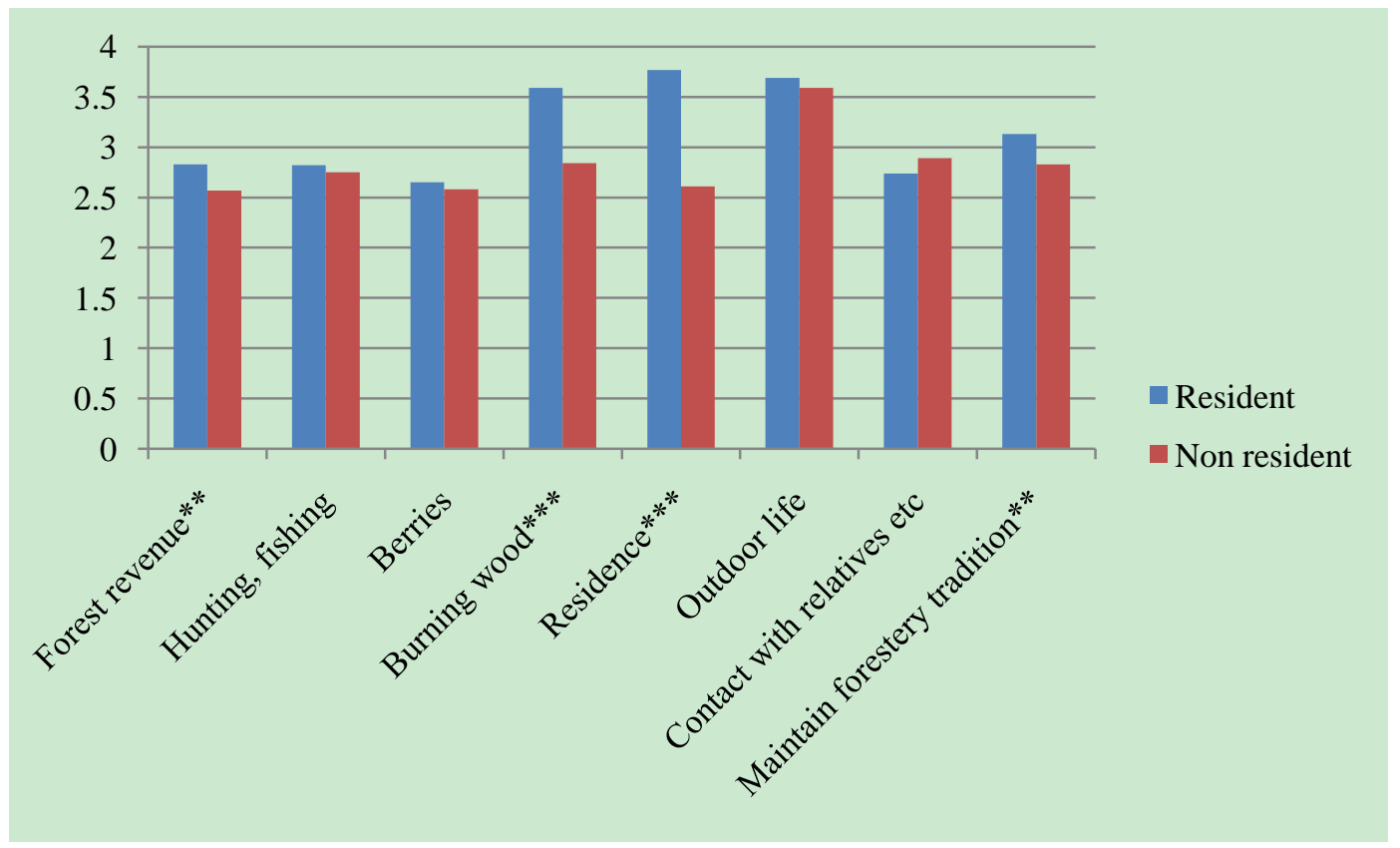

Overall, forest owners rate production values such as increased bio fuel and timber production, as well as ecological values, as important. When looking at the particular items of production and ecological values, resident owners assign more importance to increased timber production than non-resident owners do, while non-resident owners rate preservation of virgin forests higher than resident owners. However, when the items are categorized into three measures of forest values, only production values are assessed differently: Resident owners assign greater importance to production $(\mathrm{p}<0.050)$. A clearer difference in assessment of forest values is noted between men and women: Women assign greater value to the ecological aspects - they find it more important to preserve virgin forests and animals and plants - and recreational aspects of forests than men do. Men, on the other hand, find increased timber production to be more important than women do (see Figure 3). Regardless of place of residence - metropolitan or countryside - the respondents make similar assessments of forest values. Further, there is no difference between young and old owners in assessing forest values.

Forest management attitudes follow the same pattern as forest values. Resident owners put greater emphasis on the economical aspects of forest management than non-resident owners do, but there is no difference when it comes to recreational and environmental aspects, nor are there any geographic differences. Rather, differences in forest management are found between men and women (see Figure 4). Although both men and women find the economic aspects to be important, menparticularly male resident owners-assign greater importance to economic aspects of forest management than women do. Women, on the other hand, emphasize environmental and human-centered management.

To summarize, resident and non-resident owners differ in some respects, e.g., in how they have acquired their property, and how they assess forest values. Resident owners are more likely to have bought their land than are non-resident owners, a large number of resident owners live in rural areas, and forest revenue is a larger part of their total income than is the case for non-resident owners. Further, 
resident owners have stronger production forest values and stronger economic forest management attitudes.

Figure 3. Assessment of forest values among men and women. $* * * p<0.001$, ** $\mathrm{p}<0.01$, $* \mathrm{p}<0.05$.

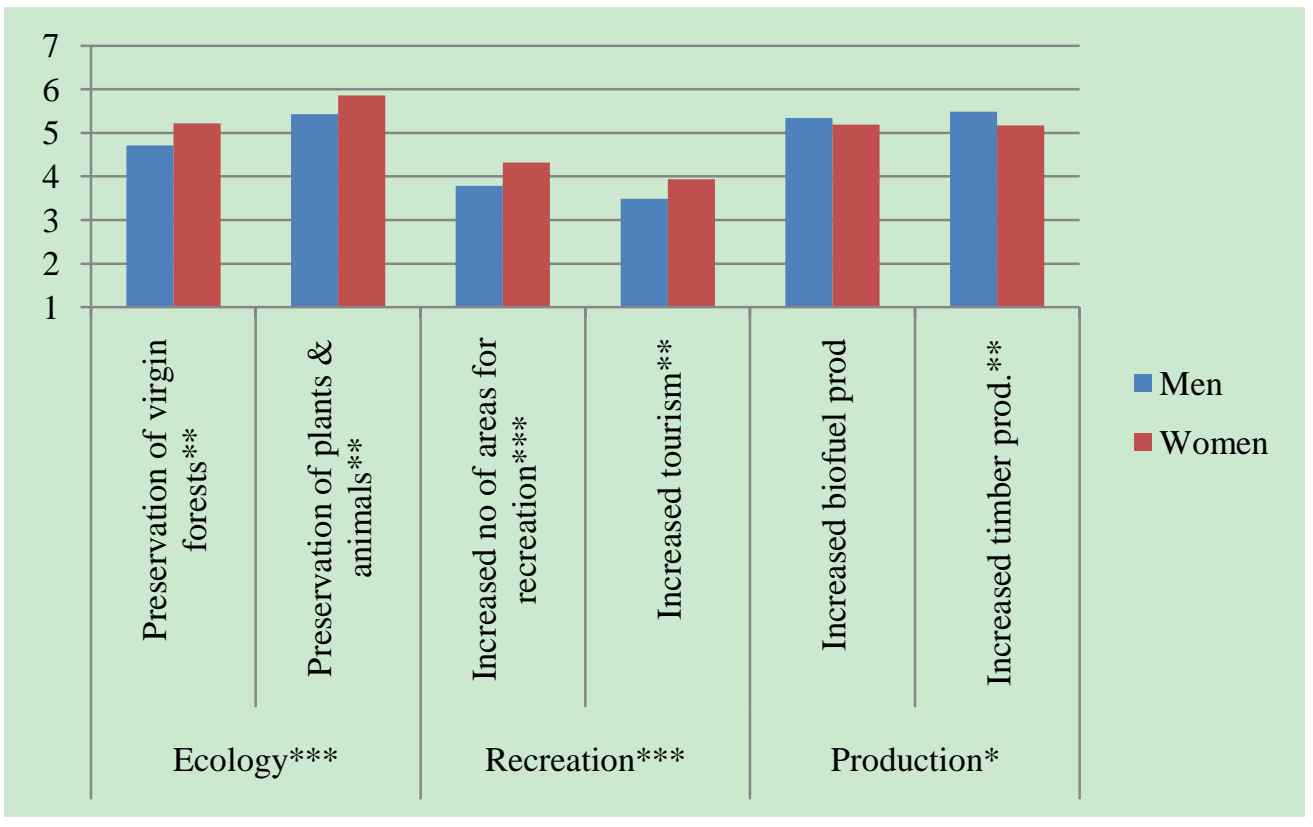

Figure 4. Forest management attitudes among men and women. *** $\mathrm{p}<0.001$, $* * \mathrm{p}<0.01, * \mathrm{p}<0.05$.

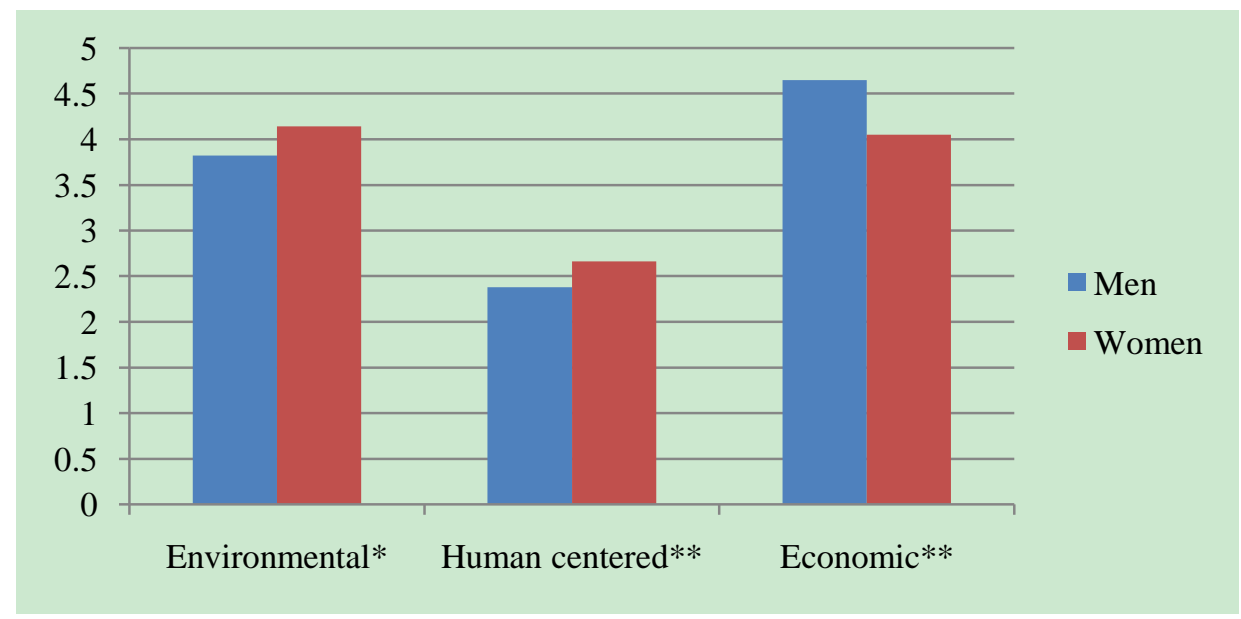

\subsection{Internal Conflict in Forest Values}

A question posed in the present study was whether forest owners have conflicting forest values, for example feeling that preservation is most important (i.e., strong ecological forest values) and that the forest should predominately be used for timber production (i.e., strong production values) at the same time, leading to an imbalance in the individual's mind, e.g., cognitive dissonance. In order to analyze whether such imbalances exist, three levels of (weak, intermediate, and strong) production values, ecological values, and recreations values were cross-tabulated against each other (see Table 3 ). 
The results of the cross-tabulations showed that there is potential ground for internal conflicts between ecological and production values. A rather large group of respondents (28\%) were found to hold both strong ecological and strong production values. The results do not indicate the existence of potential internal conflicts between production values and recreation values. When these cross-tabulations were also tested on sub-groups of interest, such as gender and residency groups, no group differences were found above and beyond those observed at the total sample level.

Table 3. Percentage of overall respondents with weak, intermediate, and strong production values cross tabulated with percentage with weak, intermediate, and strong ecological and recreation values.

\begin{tabular}{|c|c|c|c|c|}
\hline & & $\begin{array}{c}\text { Weak production } \\
\text { values }\end{array}$ & $\begin{array}{c}\text { Intermediate } \\
\text { production values }\end{array}$ & $\begin{array}{c}\text { Strong production } \\
\text { values }\end{array}$ \\
\hline \multicolumn{5}{|c|}{ Ecological - Production values } \\
\hline- & Weak ecological values & $<1 \%(3)$ & $3 \%(24)$ & $4 \%(34)$ \\
\hline- & Intermediate ecological values & $<1 \%(8)$ & $21 \%(184)$ & $22 \%(199)$ \\
\hline- & Strong ecological values & $2 \%(17)$ & $20 \%(178)$ & $28 \%(246)$ \\
\hline \multicolumn{5}{|c|}{ Recreation - Production values } \\
\hline- & Weak recreation values & $2 \%(14)$ & $12 \%(109)$ & $16 \%(139)$ \\
\hline- & Intermediate recreation values & $1 \%(10)$ & $26 \%(227)$ & $29 \%(251)$ \\
\hline- & Strong recreation values & $<1 \%(4)$ & $5 \%(45)$ & $9 \%(82)$ \\
\hline
\end{tabular}

Scale 1 to 7 ( 1 = not at all important, 7 = very important $)$.

Note: 1 to $<3=$ weak values, $3-5=$ intermediate values, $>5$ to $7=$ strong values.

4.4. The Influence of Values and Beliefs, as Controlled by Effects of Socio-Demographics, on Forest Management Attitudes

One of the present aims was to investigate whether the hierarchical structure concerning how general and specific values and beliefs influence forest management attitudes held among private forest owners.

In order to test whether values and beliefs influence forest management attitudes in a hierarchical manner, three step-wise regression analyses were conducted on the dependent variables environmental management attitudes (Step I: F(3, 713) = 55.56, p = 0.000; Step II: F(6, 713) = 109.09, p = 0.000; Step III: $F(8,713)=82.26, p=0.000$; Step IV: $F(13,713)=52.01, p=0.000)$, human-centered management attitudes (Step I: $F(3,713)=9.40, p=0.000$; Step II: F(6, 713) = 45.12, p = 0.000; Step III: $F(8,713)=33.75, p=0.000$; Step IV: $F(13,713)=21.34, p=0.000)$, and economic management attitudes (Step I: $\mathrm{F}(3,713)=11.35, \mathrm{p}=0.000$; Step II: $\mathrm{F}(6,713)=51.28, \mathrm{p}=0.000$; Step III: $\mathrm{F}(8,713)=53.18, \mathrm{p}=0.000$; Step IV: $\mathrm{F}(13,713)=36.19, \mathrm{p}=0.000)$. Basic and environmental values were entered in step one, followed by forest values in step two, and specific forest beliefs in step three. In a fourth step, we controlled the effect of a number of socio-demographics, such as gender, age, residing on forest property or not, type of region, and how the forest property was acquired. The step-wise regression allowed us to see the effects of variables early in the hierarchy, which would otherwise have been lost. The result of the three regression analyses is presented in Table 4. 
Table 4. Hierarchical regression with the influence of general values, environmental values, forest values, specific forest beliefs on three types of forest management attitudes (environmental, human centered, and economic), with beta coefficients.

\begin{tabular}{|c|c|c|c|c|}
\hline & & $\begin{array}{c}\text { Environmental } \\
\text { management } \\
\text { attitude }\end{array}$ & $\begin{array}{c}\text { Human centered } \\
\text { management } \\
\text { attitude }\end{array}$ & $\begin{array}{c}\text { Economic } \\
\text { management } \\
\text { attitude }\end{array}$ \\
\hline \multirow[t]{4}{*}{ Step I } & ST-SE & $0.14 * * *$ & -0.01 & $-0.07 \dagger$ \\
\hline & OC-C & 0.01 & 0.05 & $0.11 * *$ \\
\hline & NEP & $0.36 * * *$ & $0.19 * * *$ & $-0.15 * * *$ \\
\hline & $\operatorname{Adj} R^{2}$ & $0.19 * * *$ & $0.03 * * *$ & $0.04 * * *$ \\
\hline \multirow[t]{8}{*}{ Step II } & $S T-S E$ & 0.04 & -0.06 & -0.06 \\
\hline & $O C-C$ & 0.04 & $0.08 *$ & $0.07 *$ \\
\hline & $N E P$ & $0.07 *$ & 0.02 & 0.04 \\
\hline & Ecological forest values & $0.52 * * *$ & $0.13 * *$ & $-0.21 * * *$ \\
\hline & Recreational forest values & $0.19 * * *$ & $0.45 * * *$ & $-0.08 *$ \\
\hline & Production forest values & $-0.09 * *$ & $-0.08 *$ & $0.48 * * *$ \\
\hline & $\operatorname{Adj} R^{2}$ & $0.48 * * *$ & $0.27 * * *$ & $0.30 * * *$ \\
\hline & $\Delta \mathrm{R}^{2}$ & $0.29 * * *$ & $0.24 * * *$ & $0.26 * * *$ \\
\hline \multirow[t]{10}{*}{ Step III } & $S T-S E$ & 0.04 & -0.06 & -0.02 \\
\hline & $O C-C$ & 0.04 & $0.08 *$ & $0.07 *$ \\
\hline & $N E P$ & $0.08 *$ & 0.02 & 0.03 \\
\hline & Ecological forest values & $0.52 * * *$ & $0.13 * *$ & $-0.16 * * *$ \\
\hline & Recreational forest values & $0.18 * * *$ & $0.45 * * *$ & $-0.08 *$ \\
\hline & Production forest values & $-0.07 *$ & $-0.08 *$ & $0.31 * * *$ \\
\hline & Forest revenues & -0.04 & -0.01 & $0.19 * * *$ \\
\hline & Increased forest production & -0.03 & 0.00 & $0.23 * * *$ \\
\hline & $\operatorname{Adj} R^{2}$ & $0.48 * * *$ & $0.27 * * *$ & $0.37 * * *$ \\
\hline & $\Delta \mathrm{R}^{2}$ & 0.00 & 0.00 & $0.07 * * *$ \\
\hline \multirow[t]{15}{*}{ Step IV } & $S T-S E$ & 0.05 & -0.06 & -0.03 \\
\hline & $O C-C$ & 0.05 & $0.08 *$ & 0.03 \\
\hline & $N E P$ & $0.07 *$ & 0.02 & 0.03 \\
\hline & Ecological forest values & $0.52 * * *$ & $0.13 * *$ & $-0.15 * * *$ \\
\hline & Recreational forest values & $0.19 * * *$ & $0.45 * * *$ & $-0.07 *$ \\
\hline & Production forest values & $-0.08 *$ & $-0.07 \dagger$ & $0.29 * * *$ \\
\hline & Forest revenues & -0.03 & -0.01 & $0.21 * * *$ \\
\hline & Increased forest production & -0.02 & 0.01 & $0.23 * * *$ \\
\hline & Gender & -0.02 & -0.00 & $-0.07 *$ \\
\hline & Age & -0.03 & -0.03 & $0.14 * * *$ \\
\hline & Residency & $-0.08 * *$ & -0.03 & -0.02 \\
\hline & Type of region & 0.05 & 0.05 & -0.04 \\
\hline & Forest acquisition & 0.04 & 0.06 & 0.04 \\
\hline & Adj $R^{2}$ & $0.48 * * *$ & $0.27 * * *$ & $0.39 * * *$ \\
\hline & $\Delta \mathrm{R}^{2}$ & $0.01 *$ & 0.01 & $0.03 * * *$ \\
\hline
\end{tabular}

Note: ST-SE and OC-C are calculated factors scores based on Schwartz [39] four values types, self-transcendence, self-enhancement, openness to change, and conservation.

Control variables in step IV: Gender (Male $=1$ or Female $=2$ ), Age (continuous from 20 to 80 years of age), Residency (Resident on forest property $=1$ or Non-resident on forest property $=2$ ), Type of region $($ Big city region $=1$, Larger regional centers $=2$, Smaller regional centers $=3$, Small region $=4)$, and Forest acquisition $($ Purchase $=1$ or Inheritance $=2$ ). $* * * \mathrm{p}<0.001, * * \mathrm{p}<0.01, * \mathrm{p}<0.05, \dagger \mathrm{p}<0.070$. 
In Step I, basic values and environmental values were entered into the regression analysis with the dependent variables environmental management attitude, human-centered management attitude, and economic management attitude. The results show that basic values, but especially environmental values (NEP), have an effect on forest management attitudes. The environmental values held had a positive influence on both environmental and human-centered management attitudes and a negative influence on the economic management attitude. Self-transcendent values had a positive influence on the environmental management attitudes, while conservative values had a positive influence on the economic management attitude. Although the explained variance was significant in all three analyses, for the most part basic and environmental values showed a moderate effect on the environmental management attitude (Adj $\mathrm{R}^{2}=0.19$ ).

In Step II, forest values were entered into the regression analyses. The three types of forest valuesecologically oriented, restoratively oriented, and production oriented-all influenced the different types of management attitudes. First, we can see that basic and environmental values had a significant effect on the management attitudes in Step I. Although some influence remained significant from conservative values and NEP, in most cases the effects decreased to an insignificant level in the following steps. It can also be seen that, despite some spread effect on all three attitudes, a logical influence pattern is seen in that ecological forest values primarily had an influence on environmental management attitudes, recreation forest values primarily influenced human-centered management attitudes, and production forest values primarily influenced economic management attitudes. Forest values are seen to contribute a significant amount of explained variance for all three management attitudes, ranging from $24-29$ percent $\left(\Delta \mathrm{R}^{2}\right)$.

In the third and fourth step in the regression analyses, specific forest beliefs (Step III) and socio-demographics (Step IV) were entered. The results show that it is only in relation to economic management attitudes that specific beliefs, gender, and age show a significant influence. Believing in the importance of forest revenues and increased production in the forests as the way to meet an increase in demand do influence economic management attitudes in a positive direction. There are some socio-demographical effects on economic management attitudes, in that female respondents show a weaker economic management attitude and that age has a positive effect on that attitude. For the environmental management attitude, we see an influence of whether or not the respondent resides on his/her forest property, although a rather weak one, in that those not residing on the forest property show a weaker environmental management attitude compared to those residing on the property.

To summarize, the results from the regression analyses show that general and specific values do influence management attitudes. The strength of held environmental beliefs (NEP) primarily had the expected positive effect on environmentally oriented management attitudes, and a positive but weaker influence on human-centered management attitudes. In addition, the results showed that environmental beliefs had a negative effect on economically oriented management attitudes. Ecological forest values had the strongest effect on environmental management attitudes, but also more moderate effects on human-centered management attitudes (positive) and economic management attitudes (negative) were found. Recreation forest values had the strongest effect on human-centered management attitudes, but also showed some effect on environmental management attitudes (positive) and economic management attitudes (negative). Finally, production forest values showed a strong positive effect on economic management attitudes, while the effect on environmental and human-centered management attitudes 
was negative, but weak. The specific beliefs assessed here were the traditional focus on the importance of forest revenues on the one hand, and on the up-and-coming debate on the need for an increased production rate in forestry as a way to deal with the increased demand for forest products, on the other. As could be expected, these specific forest beliefs did influence attitudes towards forest management with an economic focus in a positive direction. However, believing that forest revenues are important and that an increased production rate in forestry is a good way to deal with an increase in demand did not influence attitudes towards forest management emphasizing ecological principles, nor those highlighting recreation interests in forest management.

Overall, general and specific values and beliefs primarily explained between approximately 30-50 percent of the variance in the dependent variables, forest management attitudes, while the influence of socio-demographics was weaker. The highest level of explained variance was found for the environmental management attitude (48\%), followed by the economic management attitude (39\%) and lastly the human-centered management attitude (27\%).

\section{Discussion and Conclusions}

The private forest owners in Sweden are older, and the already ongoing generational shift in ownership is expected to escalate. Forest ownership is undergoing a change as the share of non-resident owners is increasing, and the number of female owners is increasing. Resident owners have stronger production forest values and stronger economic forest management attitudes. Forest revenues are more important to resident owners than to non-resident owners, which might cause the latter to have more production oriented forest values and economic management attitudes.

The difference between men and women is larger than that between resident and non-resident owners. Women have stronger ecological and recreational forest values as well as environmental and human-centered forest management attitudes. This finding is in line with previous studies (e.g., [17]), and when more women come into possession of forests mainly through inheritance, a change in forest management can be anticipated.

Findings from the present study reveal no different forest values or forest management attitudes between urban and rural residents, i.e. forest owners residing in metropolitan areas assign high importance to ecological and production values, whereas recreation values score lower. This may be somewhat surprising, as studies of the public have generally shown that urban residents have higher forest protection values. However, the group in this study consists of forest owners, and it is possible that they-regardless of whether they live in an urban or rural region-regard forests as more than an area for preservation and recreation and recognize the economic benefits.

There is definitely more to values and attitudes than simply having positive and/or negative feelings about a given entity, as they also differ in strength. When strong attitudes have been established, these are resistant to change and persistent over time, and they lead to selective information processing [23]. Selective information processing also means that some seemingly relevant information is neglected. This can then build the foundation for potential conflicts between groups, but also within individuals. The results showed us that a rather large group of private forest owners strongly value both the view that the forest should predominately be used for timber production (strong production forest values) and the view that preservation is most important (strong ecological forest values). This clearly 
highlights the existence of a potential internal conflict, involving two alternatives that are equally attractive [22]. It is of great importance to identify such potential conflicts, because left unresolved they may have consequences for future forest management. For example, forestry may develop and implement forest management styles that allow for multiple forest values to be fulfilled, allowing for both high production and ecological considerations in private forestry.

Strong attitudes are consequential in that they are predictive of behavior, which has been shown in a large body of research (e.g., [23]). According to the inter-attitudinal structure of attitudes, attitude and subsequent behavior are influenced in a hierarchical manner by values and beliefs. This hierarchical structure was supported here concerning the influence of values and beliefs on forest management attitudes, which is in line with the findings of McFarlane and Boxall [35]. The present results can be taken as an indication of the relevance of using measures and models known from studies in environmental psychology research, and in studies on the motivational underpinnings of forest management attitudes. Forest management attitudes are thus influenced by basic values and environmental values, forest values and to some extent by forest-specific beliefs. Moreover, with regard to these kinds of results, the presence of multiple effects of forest values is salient. The ecological, recreational, and production forest values primarily influenced the most closely related forest management attitude, in that ecological forest values influenced the environmental view on forest management; recreation forest values influenced the human-centered form of forest management; and production forest values influenced the forest management style with an economic focus. Forest production can be increased or intensified for a number of reasons, from being driven by the financial motives of the private forest owner, to being the result of an increased demand for forest products and/or biomass, demands that could be related to a desire to decrease oil dependency. A strong belief in an increased or intensified production rate in the forests, however, was clearly related to the economically focused forest management attitudes and not to the environmentally oriented management attitudes in this sample.

Regardless of being a man or woman, resident or non-resident forest owner, there is a potential conflict of interest in forest values, as a single person can hold both strong ecological and strong production values. However, this may not necessarily pose a problem in forest management. It may in fact be an advantage for forest authorities, who are to ensure that forest management follows environmental requirements, if private forest owners accept the need (and requirements) for environmental protection. Further, a forest owner can balance strong ecological and strong production values through responsible forest management, e.g., preserving areas with high biodiversity values and allowing harvesting in other areas.

The findings from this study stress the importance to study attitudinal factors in relation to forest values and beliefs among private forests owners. There is, however, a need to further scrutinize potential impacts in forest management of a generational shift, urbanization and increasing share of non-residential forest owners. Although there are no major differences in forest values and forest management attitudes between resident and non-resident forest owners in the current study, an increasing share of non-resident forest owners may still affect the community in which the forest is located in other respects. Forest owners have a voice in issues concerning property matters in the local community (or village), e.g., matters concerning forest roads, wildlife and hunting. Not residing in the community and participating in local life on a more frequent basis, may have a negative impact on 
local social and economic development, and cause tensions between resident and non-resident land owners.

\section{Acknowledgements}

This research was funded by Future Forests, a multidisciplinary research program, and its sponsors. They are the Strategic Foundation for Environmental Research (Mistra), the Swedish University of Agricultural Sciences (SLU), Umea University, the Forestry Research Institute of Sweden (Skogforsk), and forestry industry in Sweden.

\section{References and Notes}

1. Kant, S.; Lee, S. A social choice approach to sustainable forest management: An analysis of multiple forest values in Northwestern Ontario. Forest Policy Econ. 2004, 6, 215-227.

2. Li, C.; Wang, C-P.; Liu, S-T.; Weng, L-H. Forest value orientations and importance of forest recreation services. J. Environ. Manage. 2010, 91, 2342-2348.

3. Lundmark, L. Restructuring and Employment Change in Sparsely Populated Areas. Examples from Northern Sweden and Finland; GERUM Report Series; Kulturgeografiska Institutionen, Umea Universitet: Umea, Sweden, 2006.

4. Berlin, C.; Lidestav, G.; Holm, S. Values placed on forest property benefits by Swedish NIPF owners: Differences between members in forest owners associations and non-members. Small-scale Forest Econ. Manag. Policy 2006, 5, 83-96.

5. Butler, B.J. Family Forest Owners of the United States (2006); US Department of Agriculture, Forest Services, Northern Research Station: Newtown Square, PA, USA, 2008.

6. Dutcher, D.D.; Finley, J.C.; Luloff, A.E.; Johnson, J. Landowner perception of protection and establishing riparian forests: A qualitative analysis. Soc. Natur. Resour. 2004, 17, 329-342.

7. Erickson, D.L.; Ryan, R.L.; De Young, R. Woodlots in the rural landscape: Landowner motivations and management attitudes in a Michigan (USA) case study. Landsc. Urban Plann. 2002, 58, 101-112.

8. Fischer, A.P.; Bliss, J.C. Mental and biophysical terrains of biodiversity: Conservation of oak woodland on family forests. Soc. Natur. Resour. 2006, 19, 635-643.

9. Fischer, A.P.; Bliss, J.C. Behavioral assumptions of conservation policy: Conserving oak habitat on family-forest land in the Willamette Valley, Oregon. Conserv. Biol. 2008, 22, 275-283.

10. Fischer, A.P.; Bliss, J.; Ingemarson, F.; Lidestav, G.; Lonnstedt, L. From the small woodland problem to ecosocial systems: The evolution of social research on small-scale forestry in Sweden and the USA. Scand. J. Forest Res. 2010, 25, 390-398.

11. Hugosson, M.; Ingemarson, F. Objectives and motivations of small-scale forests owners: Theoretical modeling and qualitative assessment. Silva Fenn. 2004, 38, 217-231.

12. Jacobson, M.G. Ecosystem management in the southeast United States: Interest of forest landowners in joint management across ownerships. Small-scale Forest Econ. Manag. Policy 2002, 1, 71-92.

13. Lidestav, G.; Nordfjell, T. A conceptual model for understanding the social practices in family forestry. Small-scale Forest Econ. Manag. Policy 2005, 4, 391-408. 
14. Lindkvist, A.; Mineur, E.; Nordlund, A.; Nordlund, C.; Olsson, O.; Sandstrom, C.; Westin, K. Konflikt och konsensus: Intensivodling av Skog ur ett Humanistiskt och Samhällsvetenskapligt Perspektiv; Faktaunderlag till MINT-utredningen (SLU): Uppsala, Sweden, 2009.

15. Swedish Forest Agency. Skogsstatistisk Arsbok 2010 (Yearbook of Forestry 2010); Skogsstyrelsen: Jonkoping, Sweden, 2010.

16. Tarrant, M.A.; Cordell, H.K.; Green, G.T. The public values of forests scale. J. Forest 2003, 101, 24-30.

17. Stern, P.C.; Dietz,T.; Kalof, L. Value orientations, gender, and environmental concern. Environ. Behav. 1993, 25, 322-348.

18. Ingemarson, F.; Lindhagen, A.; Eriksson, L. A topology of small-scale private forest owners in Sweden. Scand. J. Forest Res. 2006, 21, 249-259.

19. De Young, R. Expanding and evaluating motives for environmentally responsible behavior. $J$. Soc. Issues 2000, 56, 509-526.

20. Stern P.C. Toward a coherent theory of environmentally significant behavior. J. Soc. Issues $\mathbf{2 0 0 0 ,}$ 56, 407-424.

21. Zelezny, L.C.; Schultz, P.W. Promoting environmentalism. J. Soc. Issues 2000, 56, 365-371.

22. Eriksson, L.; Nordlund, A.; Westin, K. Forest values in conflict: The value and belief basis of forest management attitudes in the general public in Sweden. J. Environ. Psychol. 2011, (submitted).

23. Eagly, A.H.; Chaiken, S. The Psychology of Attitudes; Harcourt Brace Jovanovich: Fort Worth, TX, USA, 1993.

24. Eagly, A.H.; Kulesa, P. Attitudes, attitude structure, and resistance to change: Implication for persuasion on environmental issue. In Environment, Ethics, and Behavior. The Psychology of Environmental Valuation and Degradation; Bazerman, M.H., Messick, D.M., Tenbrunsel, A.E., Wade-Benzoni, K.A., Eds.; Lexington Press: San Francisco, CA, USA, 1997; pp. 122-153.

25. Olson, J.M.; Maio, G.R. Attitudes in social behavior. In Handbook of Psychology: Personality and Social Psychology; Millon, T., Lerner, M.J., Eds.; Wiley: New York, NY, USA, 2003; Volume 5, pp. 299-325.

26. Rohan, M.J. A rose by any name? The values construct. Pers. Soc. Psychol. Rev. 2000, 4, 255-277.

27. Fulton, D.C.; Manfredo, M.J.; Lipscomb, J. Wildlife value orientations: A conceptual and measurement approach. Hum. Dimens. Wildl. 1996, 1, 24-47.

28. Stern, P.C.; Dietz, T.; Kalof, L.; Guagnano, G.A. Values, beliefs, and proenvironmental action: Attitude formation toward emergent attitude objects. J. Appl. Soc. Psychol. 1995, 25, 1611-1636.

29. Manning, R.; Valliere, W.; Minteer, B. Values, ethics, and attitudes toward national forest management: An empirical study. Soc. Natur. Resour. 1999, 12, 421-436.

30. Schultz, P.; Zelezny, L. Values as predictors of environmental attitudes: Evidence for consistency across 14 countries. J. Environ. Psychol. 1999, 19, 255-265.

31. Schwartz, S.H. Are there universal aspects in the structure and contents of human values? J. Soc. Issues 1994, 50, 19-45.

32. Stern, P.C.; Dietz, T. The value basis of environmental concern. J. Soc. Issues 1994, 50, 65-84. 
33. Stern, P.C.; Dietz, T.; Guagnano, G.A. The new ecological paradigm in social-psychological context. Environ. Behav. 1995, 27, 723-753.

34. Vaske, J.; Donnelly. M.A value-attitude-behavior model predicting wildland preservation voting intentions. Soc. Natur. Resour. 1999, 12, 523-537.

35. McFarlane, B.L.; Boxall, P.C. Factors influencing forest values and attitudes of two stakeholder groups: The case of the Foothills model forest, Alberta, Canada. Soc. Natur. Resour. 2000, 13, 649-661.

36. McFarlane, B.L.; Boxall, P.C. The role of social psychological and social structural variables in environmental activism: An example of the forest sector. J. Environ. Psychol. 2003, 23, 79-87.

37. McFarlane, B.L.; Hunt, L.M. Environmental activism in the forest sector: Social psychological, social-cultural, and contextual effects. Environ. Behav. 2006, 38, 266-285.

38. Rokeach, M. Beliefs, Attitudes, and Values: A Theory of Organization and Change; Jossey-Bass: San Francisco, CA, USA, 1968.

39. Schwartz, S.H. Universals in the content of and structure of values: Theoretical advances and empirical tests in 20 countries. Adv. Exp. Soc. Psychol. 1992, 25, 1-65.

40. Nordlund, A.; Garvill, J. Value structures behind proenvironmental behavior. Environ. Behav. 2002, 34, 740-756.

41. Dunlap, R.E.; van Liere, K.D. New environmental paradigm. J. Environ. Educ. 1978, 9, 10-19.

42. Dunlap, R.E.; van Liere, K.D.; Mertig, A.G.; Jones, E.R. Measuring endorsement of the new ecological paradigm: A revised NEP scale. J. Soc. Issues 2000, 56, 425-442.

43. Naess, A.; Rothenberg, D. Ecology, Community and Lifestyle: Outline of an Ecosophy; Cambridge University Press: Cambridge, UK, 1989.

44. Eckersley, R. Environmentalism and Political Theory: Toward an EcocentricAapproach; UCL Press: London, UK, 1992.

45. Grendstad, G.; Wollebaek, D. Greener still? An empirical examination of Eckersley's ecocentric approach. Environ. Behav. 1998, 30, 653-675.

46. Thompson, S.C.G.; Barton, M.A. Ecocentric and anthropocentric attitudes toward the environment. J. Environ. Psychol. 1994, 14, 149-157.

47. De Groot, J.I.M.; Steg, L. Value orientations and environmental beliefs in five countries. Validity of an instrument to measure egoistic, altruistic and biospheric value orientations. J. Cross Cult. Psychol. 2007, 38, 318-332.

48. Thunberg, B. Socioekonomiska forutsattningar-varderingar och prioriteringar hos markagare, intressegrupper, allmanhet, regionala forutsattningar m.m.. In Sex Omvarldsanalyser for Framtidens Skog_Hallbara Strategier under Osakerhet; MISTRA: Norrkoping, Sweden, 2006; pp. 39-53.

49. Creighton, J.L. The use of values: Public participation in the planning process. In Public Involvement and Social Impact Assessment; Daneke, G.A., Garcia, M.W., Delli Priscolli, J., Eds.; Westview Press: Boulder, CO, USA, 1983; pp. 143-160.

50. Carrow, R. Integrated resource management-A case-study of unrealized potential. Forest Chron. 1994, 70, 19-21.

51. Robinson, D.W.; Robson, M.; Rollins, R. Towards increased citizen influence in Canadian forest management. Environments 2001, 29, 21-41. 
52. Carrow, R. Canada's model forest program: Challenges for phase II. Forest Chron. 1999, 75, 73-79.

53. Harshaw, H.W.; Tindall, D.B. Social structure, identities, and values: A network approach to understanding people's relationships to forests. J. Leisure Res. 2005, 37, 426-449.

54. Bengtson, D.N.; Xu, Z. Trends in national forest values among forestry professionals, environmentalists, and the new media, 1982-1993. Soc. Natur. Resour. 1997, 10, 43-59.

55. Vaske, J.J.; Donnelly, M.P.; Williams, D.R.; Jonker, S. Demographic influences on environmental value orientations and normative beliefs about national forest management. Soc. Natur. Resour. 2001, 14, 761-776.

56. Winter, C. Preferences and values for forests and wetlands: A comparison of farmers, environmentalists, and the general public in Australia. Soc. Natur. Resour. 2005, 18, 541-555.

57. Stern, P.C. The psychological dimensions of global environmental change. Annu. Rev. Psychol. 1992, 43, 269-302.

(C) 2010 by the authors; licensee MDPI, Basel, Switzerland. This article is an open access article distributed under the terms and conditions of the Creative Commons Attribution license (http://creativecommons.org/licenses/by/3.0/). 